\title{
The New Evolution Trend of the International Financial Structure and the Countermeasures China Should Adopt in the Financial Crisis Perspective
}

\author{
Wang Hongzheng ${ }^{1}$ \\ ${ }^{1}$ Shenzhen Polytechnic, Guangdong City, Shenzhen Province, 518055
}

Keywords: International Financial Structure, Financial Crisis, New Trend, China, Countermeasures

\begin{abstract}
Many new trends appear in international financial situation in this century. The financial crisis of European countries made the existing international financial order is under increasing pressure. There are more and more fierce competition among Western countries and the BRIC countries for the international financial right to speak. Facing the new international financial order that may arise in the future, China should adopt a series of targeted measures, actively participate in international financial cooperation in the era of globalization, and gradually build and expand China's international financial discourse.
\end{abstract}

\section{Introduction}

In recent years, China's economic strength has increased trade, has become the world's largest developing country, economies of scale and the scale of foreign trade after the United States, ranking second in the world, foreign currency reserves ranking first in the world. However, compared to China's trade status economy, China's international financial status is still not steady and it does not match China's economic and trading power and identity. The last century and the beginning of this century, international financial issues reflect today's spate of world financial system has serious drawbacks, such that in the current international financial situation can be described as troubled times. Especially in 2007-2010 originated in the US Wall Street "subprime" crisis of the international financial crisis has further revealed the one hand, the United States as the representative of the Western developed countries in the international financial structure and long-term resident hegemony, developing countries in the current international financial structure belonging to subordinate and passive position, on the other hand the United States and other developed countries did not assume its financial hegemony corresponding international responsibilities, with the continuous development of economic globalization, led to financial problems inside these countries is extremely easy and quickly transfer to the world, resulting in more dangerous areas of the broader global financial crisis. A correct understanding of the international financial structure, accurately grasp the development of the world financial law, science and the development of international and domestic financial Countermeasures for deepen financial reform, accelerate financial development, maintaining financial stability, and promote the internationalization of RMB, improve China's comprehensive national strength has important significance [1].

\section{The Meaning of the International Financial Structure}

The so-called international financial situation means an international financial market in the various countries with the existing financial resources and the financial system after each game formed a relatively stable situation. 'A financial situation in the country is reflected in the country's financial system, the financial system is the basic framework for an economy flows, layman's terms is a flow situation to national currencies. In this sense, the fundamental problems in the financial structure or the currency issue. 


\section{The New Trend of the Current International Financial Structure}

The financial crisis of European countries and United States led to the international financial discourse of western countries being challenged. In 2007 the outbreak of the subprime crisis spread gradually evolved into a financial crisis in global financial markets has a negative impact on the global economy but also hurt the real economy, the United States itself. US domestic economy has not yet completely out of the shadow of the financial crisis, the risk of a double-dip recession remains high. The fuse of the European debt crisis is Greece's debt crisis, a direct result of the government's debt default risk of the fiscal deficit. Spain, Italy, Portugal, Ireland, France and other euro-zone countries has recently been found in a series of financial risks. One after another outbreak of the European financial crisis is shaking the international financial discourse past dominated by the Western countries and the absolute confidence of developing countries, especially the emerging economies of the current international financial system has dropped to historic lows. As the global voice for reform of the international financial system, increasing international financial transfer of the right to speak by the United States and Europe to emerging economies is gradually becoming a new trend [2].

East Asian financial cooperation gradually formed the new paradigm of international currency competition. Given the international financial crisis, the exchange rate risk in international financial markets and the dollar increased uncertainty, signed a series of currency swap agreements among East Asian countries, in providing liquidity to each other support, while greatly reducing the risk of financing costs and exchange rate fluctuations. Especially since June 2012 RMB and the yen began to direct exchange, it ended a long rely calculate the exchange rate between the US dollar and Japanese history, in addition to the dollar yen to become the first to conduct direct transactions with RMB major foreign currencies, not only the proportion of the dollar decline in bilateral settlement, and the RMB in bilateral settlement and the pricing is more often used to gradually strengthen the RMB's status as a regional core currency. East Asia is the world's most dynamic economic growth and trade in the region, increasingly close financial cooperation between the region's major economies, the dollar dominance in international settlement in the region is greatly reduced. In the current world super-sovereign currency does not appear to play a background function essentially regional common currency, the East Asian region is gradually forming a new international currency competition the new paradigm (Paradigm). It is foreseeable that the coming period, which will further deepen the development of the new paradigm, and may lead to large changes in an international monetary dominance [3].

The competition among different economies in the international financial institutions is intensified. Currently, the two traditional international financial institutions the World Bank and the International Monetary Fund are also facing growing pressure to change in the international financial situation in the context of upheaval. As a representative of the world's emerging economies, Brazil, Russia, India, China, South Africa and other emerging markets and developing countries have asked to promote global economic governance reform, increase in emerging markets and developing countries in the World Bank and the International Monetary Fund in representation and voice, change the United States through a veto to manipulate the reality of the international financial institutions. Voting rules of these international financial institutions are remnants of the Bretton Woods system after World War II, it has been totally inconsistent with the pattern of international economic and political realities of the 21st century requirements. These rules are to be reformed if not fundamentally, the US international economic organizations continue to dictate the use of international economic organizations and even other countries to suppress the phenomenon of the world financial crisis to pass difficult to prevent and stop fundamentally. It can be said that the future for a long period of time inside the two voting Game international financial institutions will be intensified and its internal pressure for reform will continue to increase. 


\section{The Countermeasures China Should Adopt to Face the Future New International Financial Order}

Give priority to key areas to accelerate the process of internationalization of the RMB. With the outbreak of the financial crisis, European and American countries have been the original of the international monetary system has been seriously hit, many countries have put forward ideas "super-sovereign state money", hoping to slow the financial crisis on the Western countries to bring their economies. It shocks, but the lack of real operability and difficult to put into practice in the short term. RMB internationalization trend emerged in recent years, although it also steadily, but the distance between the RMB to become an international settlement and reserve currency like the dollar is still a long way to go [4].

We now need to think about is the formation of a transitional arrangements for the international monetary system as soon as possible, so that the world monetary system before the issue of a final settlement can reduce dependence on the dollar. In this international context, East Asia, Southeast Asia, Central Asia, Africa should be focused on promoting the internationalization of the RMB area. Since the establishment and development of Japan and South Korea and the ASEAN Free Trade Area, the RMB settlement in the region in the use of international scope has expanded rapidly, and thus the internationalization of RMB first breakthrough in East and Southeast Asia is a real possibility. Central Asian countries and African countries in the international economic and trade cooperation framework of the Shanghai Cooperation Organization and the China-Africa Cooperation Forum in recent years has also made leaps and bounds, these countries after the financial crisis for the West to use the RMB international settlement also calls for more be higher. We are in the process of promoting the internationalization of the RMB must adhere to the "focused, realistic, detours" principle, on a global scale in selected key areas pilot and gain experience, this is the most practical feasibility of choice.

Take advantage of emerging international organizations to build an international financial discourse. In the future Chinese participation in building a new international financial order will have to face many difficulties, the most intractable problem is China the right to speak in international financial affairs. The current major international financial right to speak are vested in the hands of the Western developed economies, improve financial right to speak Chinese it is already difficult in the existing framework. In recent years the BRICS Organization and the Shanghai Cooperation Organization has made increasingly broad consensus on financial cooperation, these new international financial cooperation to enhance the rapid development of our international financial discourse is very favorable.

From the current situation, the Shanghai Cooperation Organization, the Commonwealth Bank has been established to open up a new field of financial cooperation between the European and Asian governments, so that China play a role in the neighboring countries through development finance has taken an important step. Future cooperative bank may be established BRIC countries also try to fight for a greater voice in the international financial system. BRIC will become a cooperative bank and the World Bank, the International Monetary Fund similar to the international financial institutions, but will be more focused on the financial needs of emerging economies. In these emerging international organizations operating in China through the formation of economic and monetary union, free trade area, a common capital markets and other ways to expand the breadth and depth of financial cooperation with the world's emerging economies, the development is conducive to the emerging economies of the international financial system specification, and gradually build a comprehensive set of international financial right to speak, as in the era of globalization to expand our national interests.

Have a "fresh start" in preparation for a new international financial order. Due to the changing times and the Western countries in the global economy relative decline in the absolute dominant position, and we should not and cannot be expected to present a series of talks and consultations on the new international financial order to produce a similar 1944 that forced the Bretton Woods system of the international financial system binding provisions. Globalization of the 
world after World War II brought significant economic benefits and China is one of the main beneficiaries. We are asked to exercise greater voting rights to the World Bank and the IMF, but also should clearly understand the nature of these major established and dominated by western countries on the international financial institutions is a continuation of the Western world the rules of the game, since modern times In Western countries, a symbol of the global economic and political hegemony. China as a rapidly growing economic strength of ancient civilization in the face of changing times and rapidly changing world, a new international financial order should have a more long-term future of the goal. While actively participate in the reform of the existing international financial order, China should also have "fresh start" in preparation, design and build a progressively in line with the national interests of our country a new international financial order [5].

Any international organization are not always there, any kind of world order have to face the world trend changes. From large historical perspective, international financial order in the world today is only a temporary phenomenon of human economic life. China wants to occupy in the future world economic competition and the interests of the game in a good position and enhance their financial rights discourse in the international financial order, we should not just pin their hopes on the reform of the existing international financial order. We actively participate in the future in addition to the reform of the existing international financial institutions, fundamentally speaking should also "take the initiative" to establish a new set of international financial organizations to advance the 21st century to build a new international financial order.

\section{Conclusion}

Since the early 2000s, many emerging developing countries has emerged faster economic growth, while developed economies in the same period have generally weak economic growth with high unemployment and in debt crisis-prone state. The emerging imbalances of economic growth between developed and developing countries have some profound impact on the current international financial situation and make the world financial situation gradually showing a series of new trends. The emergence of these new trends requires our country to take a new approach in the new international financial situation.

\section{References}

[1] X.Zhang, Financial crisis theory evolution and development, J. Business Research, 5(2007) 46-47.

[2] C.Li, Theory summary and outlook of financial center development, J. Shanghai Financial. 11(2006) 26-30.

[3] C.Y.Wang, Some thoughts on financial center, J. Shanghai Financial. 12(2009) 56-58.

[4] J.X.Li, Inherent laws of formation and development of the financial center, J. Commercial Research .9(2009) 19-22.

[5] Y.X.Zhang, Experience and enlightenment of foreign financial center formation and development, J. Economic issues. 4(2007) 129-132. 